graphies, I have ventured to give very briefly the information required.

The so-called burning well has ceased to exist for nearly a century. It was fed by a spring; and petroleum and naphtha also found their way from rents in the rock into the well with the water, and were occasionally ignited. Springs of petroleum, on a much larger scale than the Broseley one, are met with in the neighbourhood, and the yield of each of these was formerly much greater than at present. Many hogsheads from one of these were exported some years ago, under the name of 'Betton's British Oil.' The rocks were tapped by driving a level through one of the sandstone rocks of the Coal-measures; but these are now drained, and very little is found to flow from them. 'This is also the case with a spring in Tar-Batch Dingle, about a mile and a half lower down the Severn: the tarspring is still to be seen, but the quantity given out is smaller, we apprehend, than when it first gave its name to the Dingle.

With regard to its origin, it is well known that many of the trees of the Carboniferous period were resinous, like our pines; and it is easy to suppose that the oil pressed out from the accumulated masses of vegetable matter which formed the coal-seams would become absorbed by the sand-beds above them, and that this oil would naturally find its way out when tapped by shafts, or levels, or watercourses.

MADRLEY, SALOP: April 24, 1865. John RANDALL, F.G.S.

\title{
ARE THE SEA-ROCKS OF CHARNWOOD FOREST LAURENTIAN?
}

To the Editor of the Geological Magazine.

Sir,-In the last number of the Geological Magazine, Sir R. Murchison, in his paper 'On the Laurentian Rocks of Great Britain, Bavaria, and Bohemia,' brings prominently into notice the strike of the beds of the old rocks of the North-west Highlands (fundamental gneiss) as being a feature distinguishing them from the Cambrian and other aqueous rocks of our Island. It may be useful to notice that the old slate-rocks of Charnwood Forest have precisely this same strike, viz. S.E. by N.W. These rocks, covering an irregular square of about ten miles, have been (doubtfully, I think) classed as 'Cambrian.' They have many features that distinguish them from the 'typical Cambrians' of the 'Longmynd;' among these may be noticed the great variety of rocks, -four species of so-called igneous rock (Granite, Syenite, Greenstone, and Basalt*)-almost every variety of slate, from coarse-grained grauwacké to fine roofingslate,- the remarkable metamorphic character of the whole group: slate passing by insensible gradations into greenstone, and the occurrence of gneiss, in almost close contact with granite; there

* I have part of a fine hexagon from the anticlinal line: it is a coarse-grained basalt. 
are also some beds which may turn out to be altered limestones; and then, this group is really an old mountain-chain, having an anticlinal line, which (if the beds had not been broken through and broken up at the same time) would have given a ridge of many thousand feet high. These features, I think, distinguish this group of rocks from the Cambrians of Wales.

James Plant.

\section{To the Editor of the Geological Magazine.}

Sir,-In your last Number, under the head of 'Proceedings of the Glasgow Geological Society,' a paper is reported to have been read 'On the Discovery of Lower Carboniferous Fossils in the Upper Coal-measures;' and it is stated that they were discovered ' bigher in the Carboniferous series than previously known.'

I beg to state that this is not the first discovery of marine forms in the Upper Coal-measures. They were discovered, several years ago, by Messrs. Hull and Green, of the Geological Survey, at Ashton-under-Lyne, in Upper Measures. Shortly afterwards, I had the good fortune to discover them in the upper part of the North Staffordshire Coal-field._-I am, \&c.

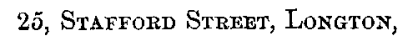
STAFFORDSHIRE.

\section{To the Editor of the Geological Magazine.}

SIr,-I enclose some samples of a mineral I discovered about a year ago in some clay-land $I$ have near the Humber-side at this place. I had a quantity of the clay dug, with a view of finding out what fossils it contained at a lower depth than it is common to dig it ont for the purpose of making bricks. The clay at the surface is brownish in colour, but gradually becomes blue as you go lower, and at about ten feet deep is nearly black, very 'sludgy', and apparently contains a great deal of vegetable matter. At about seven or eight feet I took a lump of the clay, and, kneading it in my hand, felt something prick me : I found what looked like small twigs, of from half an inch to an inch long, and varying from about the thickness of an average pin, to three or four times that thickness-but evidently iron or metal of some kind. I tried it with the magnet, and found it flew to it at once. I have since found that it is itself magnetic, and that when slightly filed it will attract small steel filings. I showed a sample of it to Dr. Percy several months ago; and I understood him to say that the 'structure' was new to him, but that he would make some enquiry about it; but as $I$ have heard nothing from him on the subject, I presume he has forgotten all about the matter. I have therefore thought it my best plan to write this letter to you, thinking that either yourself or some of your many readers and contributors may perhaps kindly favour me by saying whether it is usual to find in such a place such a mineral.-I remain, \&c.,

Alfred Henry Pecheld, Barrister-at-law.

Banton-on-Humber: Féb. 18, 1865, 